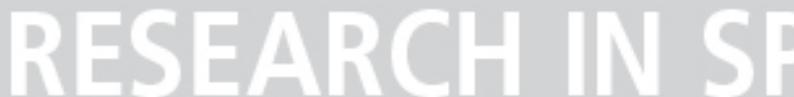 \\ DHYSICAI
}

The effect of antihypertensive medication and exercise training on functional status in hypertensive older adults

Autor(es): $\quad$ Baptista, Liliana Carina Pereira; Martins, Raúl A.

Publicado por: Imprensa da Universidade de Coimbra

URL persistente:

URI:http://hdl.handle.net/10316.2/44146

DOI:

DOI:https://doi.org/10.14195/2182-7087_ex2018_83

Accessed : $\quad$ 26-Apr-2023 01:50:24

A navegação consulta e descarregamento dos títulos inseridos nas Bibliotecas Digitais UC Digitalis, UC Pombalina e UC Impactum, pressupõem a aceitação plena e sem reservas dos Termos e Condições de Uso destas Bibliotecas Digitais, disponíveis em https://digitalis.uc.pt/pt-pt/termos.

Conforme exposto nos referidos Termos e Condições de Uso, o descarregamento de títulos de acesso restrito requer uma licença válida de autorização devendo o utilizador aceder ao(s) documento(s) a partir de um endereço de IP da instituição detentora da supramencionada licença.

Ao utilizador é apenas permitido o descarregamento para uso pessoal, pelo que o emprego do(s) título(s) descarregado(s) para outro fim, designadamente comercial, carece de autorização do respetivo autor ou editor da obra.

Na medida em que todas as obras da UC Digitalis se encontram protegidas pelo Código do Direito de Autor e Direitos Conexos e demais legislação aplicável, toda a cópia, parcial ou total, deste documento, nos casos em que é legalmente admitida, deverá conter ou fazer-se acompanhar por este aviso. 


\section{ANNALS OF RESEARCH IN SPORT AND PHYSICAL ACTIVITY}




\title{
THE EFFECT OF ANTIHYPERTENSIVE MEDICATION AND EXERCISE TRAINING ON FUNCTIONAL STATUS IN HYPERTENSIVE OLDER ADULTS
}

\author{
Liliana Carina Pereira Baptista ${ }^{1}$; Raúl A. Martins ${ }^{1}$
}

KEYWORDS: Diuretics; Calcium channel blockers; $\beta$ - blockers; Exercise; Functional Status.

\section{INTRODUCTION}

Over the last decade, an increasingly prevalence of functionally-limited hypertensive individuals ${ }^{(1)}$, highlights the need to identify interventions capable to reduce hypertensionaging- disability burden and maximize an healthy aging ${ }^{(2)}$.Thus, in context of the preceding trends, the aims of the present study is to compare the effect of three types of antihypertensive treatment in response to chronic exercise training on functional status in independently hypertensive older adults with comorbidities: i) thiazide diuretic's medication (D); ii) calcium channel blockers (CCB); iii) $\beta$ - blockers medication ( $\beta B$ ).

\section{METHODS}

This 2-year un-randomized longitudinal cohort study included 96 hypertensive older adults that underwent one of the following 3 conditions: i) thiazide- related diuretics medication ( $\mathrm{D} ; n=33)$; ii) calcium channel blockers medication (CCB; $n=23$ ); iii) and $\beta$-blockers medication ( $\beta \mathrm{B} ; n=40)$. Baseline and follow-up evaluations included the Senior Fitness Test battery, Short Form Health Survey 36 (SF-36), the health history questionnaires, anthropometric and hemodynamic profile. Results All groups improved the physical functional status, particularly upper and lower body strength and aerobic endurance and systolic blood pressure. The $D$ and $\beta B$ groups also improved the waist circumference and body mass. The

1 Universidade de Coimbra- Faculdade de Ciências do Desporto e Educação Física.

Email: libaptista10@hotmail.com 
CCB decreased total cholesterol $(P=0,028)$, presented better physical functioning, physical component score but also augmented bodily pain. The $\beta B$ group decreased triglycerides ( $P$ $=0.013$ ). No group differences were found.

\section{CONCLUSIONS}

Functional status improves with antihypertensive medication jointly with exercise training. Independently of the antihypertensive medication choice, exercise training plus antihypertensive therapy should be recommended into the standard prescription practice to reduce the rate of physical disability among hypertensive older adults.

\section{REFERENCES}

1. Hajjar, I. et al., 2016. Racial Disparity in Cognitive and Functional Disability in Hypertension and All-Cause Mortality. American Journal of Hypertension, 29(2), pp.185-193.

2. Buford, T.W., 2016. Hypertension and aging. Ageing Research Reviews, 26, pp.96-111. 